Kamil Olender

ORCID: 0000-0001-9322-0915

Uniwersytet Wrocławski

https://doi.org/10.19195/1733-5779.38.20

\title{
Populizm i globalny kryzys demokracji w kontekście współczesnych mechanizmów medialnych
}

Słowa kluczowe: demokracja, social media, media, komunikacja, populizm

Keywords: democracy, social media, media, communication, populism

Abstrakt: Celem artykułu jest przyjrzenie się bieżącym tendencjom konsumpcji medialnej w kontekście erozji procesów demokratycznych na przykładzie wybranych państw na świecie oraz próba znalezienia odpowiedzi na pytanie, czy sposób, w jaki skonstruowane są media wpływa na wzmożenie i popularyzację ruchów autokratycznych i populistycznych. Przyjęto wstępną hipotezę badawczą wskazującą, że działanie mediów i kształtowane przez nie przyzwyczajenia konsumenckie odbiorców znacząco wspierają komunikacje antydemokratycznych aktorów sceny politycznej.

\section{Populism and the global crisis of democracy in the context of contemporary media mechanisms}

\begin{abstract}
The main aim of this article is to investigate the current trends in media consumption in the context of democracy erosion based on the examples of chosen countries. The author is seeking answers to the question whether the way the media are created has an influence on the popularization of autocratic and populist movements. A preliminary research hypothesis was adopted that indicates that the operation of the media and the consumer habits of recipients created by them significantly support the communication of anti-democratic actors of the political scene.
\end{abstract}

\section{Wstęp}

Ostatnie lata przyniosły wiele zmian na gruncie polityki poszczególnych państw - to właśnie w tym czasie licznie zaczęły pojawiać się głosy podające w wątpliwość mozolnie budowany prymat demokracji pośredniej, choć jeszcze dwie dekady wcześniej wydawało się, że obrany kierunek jest powszechnie akceptowany i nienaruszalny przez lata. Debaty, toczone nie tylko u zmierzchu XX wieku, lecz także już znacznie wcześniej, koncentrowały się coraz częściej na 
odejściu i malejącym znaczeniu największych nurtów politycznych, co nierzadko określano nawet mianem końca ideologii ${ }^{1}$. Pisano także o powrocie do Arystotelesowskiej koncepcji polityki kompromisu i konsensusu ${ }^{2}$, w którym to ujęciu zgodę można osiągnąć poprzez szeroki podział władzy, debaty oraz dyskusję pomiędzy poszczególnymi konkurującymi ze sobą aktorami sceny politycznej ${ }^{3}$. Najgłośniejszym echem odbiły się słowa amerykańskiego politologa Francisa Fukuyamy ${ }^{4}$ o zakończeniu debat ideologicznych skutkującym bezapelacyjnym zwycięstwem na świecie demokracji liberalnej. „Koniec historii”, jak określił ten stan Fukuyama, wiązał się z przyjęciem przez większość państw modelu i ustroju politycznego rządów ludu, propagowanego przez kraje zachodniej Europy i USA. Początek XXI wieku pokazał jednak, że pozycja demokracji liberalnej nie jest wcale tak stabilna, jak zapowiadano.

Celem niniejszego artykułu jest przyjrzenie się bieżącym tendencjom konsumpcji medialnej w kontekście erozji procesów demokratycznych na przykładzie wybranych państw na świecie oraz próba znalezienia odpowiedzi na pytanie, czy sposób, w jaki skonstruowane są media, wpływa na wzmożenie i popularyzację ruchów autokratycznych i populistycznych. Przyjęto wstępną hipotezę badawczą wskazującą, że działanie mediów i kształtowane przez nie przyzwyczajenia konsumenckie odbiorców znacząco wspierają komunikację antydemokratycznych aktorów sceny politycznej. Dla osiągnięcia powyższych celów i weryfikacji hipotez przeanalizowano aktualną i adekwatną literaturę z zakresu politologii i nauki o komunikacji społecznej i mediach w poszukiwaniu funkcjonalności mediów, wykorzystywanych w celach propagowania postaw antydemokratycznych i populistycznych.

\section{Kryzys demokracji na świecie - tło}

Rokroczne raporty i rankingi dotyczące stanu demokracji w poszczególnych państwach świata można odbierać dwojako: pozytywnie — ponieważ pozwalają odnotować dalszy rozwój demokratyzacji w krajach z czołówki listy, czyli tych, których pozycja społeczno-polityczna jest ustabilizowana, jak na przykład Szwecja, Norwegia, Islandia — ale też negatywnie, gdyż informują, że w ujęciu całościowym demokracje uległy znacznemu osłabieniu (pokazują to chociażby democracy index autorstwa The Economist Intelligence Unit ${ }^{5}$, jak i kolejne raporty publikowane przez międzynarodowy zespół badawczy, tworzący Instytut

${ }^{1}$ Zob. D. Bell, The End of Ideology? On the Exhaustion of Political Ideas in the 1950s, New York 1960.

2 A. Heywood, Politologia, przeł. B. Maliszewska et al., Warszawa 2006, s. 11-12.

3 Zob. B. Crick, W obronie polityki, przeł. A. Waśkiewicz, Warszawa 2004.

${ }^{4}$ F. Fukuyama, Koniec historii, przeł. T. Bieroń, M. Wichrowski, Poznań 1997, s. 87.

5 The Economist Intelligence Unit, Democracy Index 2020: In sickness and in health?, www. eiu.com/topic/democracy-index (dostęp: 25.05.2021). 
V-Dem ${ }^{6}$ ). Wydarzenia ostatnich lat pokazały, że wspominany przez Francisa Fukuyamę „koniec historii” może być w rzeczywistości początkiem końca historii demokracji w dominującym dotychczas ujęciu liberalnym. Obserwowany rosnący dystans wobec aktualnego modelu demokracji oraz widoczne zachwianie ich wiary w ten model zdają się znajdować potwierdzenie w spektakularnych wydarzeniach ostatnich lat, takich jak wystąpienie Wielkiej Brytanii z Unii Europejskiej, prezydentura Donalda Trumpa w Stanach Zjednoczonych, rządy Viktora Orbána na Węgrzech czy wreszcie wzrost popularności takich partii jak Partia Wolności w Niderlandach, Liga Północna we Włoszech, Podemos w Hiszpanii, Jobbik na Węgrzech, Alternatywa dla Niemiec czy Front Narodowy we Francji, które wprost kontestują panujący porządek prawny, polityczny, a nawet ustrojowy ${ }^{7}$. Fakt zaistnienia kryzysu demokracji (w niniejszej publikacji rozumianego jako współwystępowanie takich czynników jak wzrost zainteresowania wyborców partiami populistycznymi, postępująca autokratyzacja rządów, ograniczanie poszczególnych praw obywatelskich lub funkcjonowania instytucji demokratycznych) jest potwierdzony także bogatą literaturą naukową ${ }^{8}$, wśród której można znaleźć także sporo opracowań dotyczących sytuacji Polski ${ }^{9}$.

Mimo że poparcie dla demokracji pośredniej w wielu krajach na świecie jest wysokie lub bardzo wysokie (w USA i Europie średnio tylko co dziesiąta osoba nie jest zwolennikiem demokracji ${ }^{10}$, to w ujęciu globalnym średni poziom demokratyzacji obniżył się aktualnie do poziomu, jaki odnotowano ostatnio w 1990 roku, co w największej mierze dotknęło Indie, centralną Azję, kraje Ameryki Łacińskiej oraz państwa Europy Wschodniej ${ }^{11}$. Przyglądając się strategiom aktorów politycznych kwestionujących porządek demokratyczny w takich krajach

6 V-Dem, Autocratization Turns Viral. Democracy Report 2021, https://www.v-dem.net/media/ filer_public/74/8c/748c68ad-f224-4cd7-87f9-8794add5c60f/dr_2021_updated.pdf (dostęp: 7.05.2021).

7 Zob. S. Blombäck, Populism as a challenge to liberal democracy in Europe, [w:] The European Union in a Changing World Order, red. A. Bakardjieva Engelbrekt et al., Cham 2020; L. Diamond, Democracy Demotion: How the Freedom Agenda Fell Apart, „Foreign Affairs” 98, 2019, nr 2; J.-W. Müller, Co to jest populizm?, przeł. M. Sutowski, Warszawa 2017; R. Eatwell, M. Goodwin, Narodowy populizm. Zamach na liberalna gospodarke, przeł. W. Kurylak, Katowice 2020.

8 Zob. R. Eatwell, M. Goodwin, op. cit.; E.W. Ross, The problem of democracy in the time of Trump, „Educazione Aperta” 2020, nr 6, s. 139-151.

9 Zob. T. Drinóczi, A. Bień-Kacała, Illiberal Constitutionalism: The case of Hungary and Poland, „German Law Journal” 20, 2019, nr 8, s. 1140-1166; A. Jaskulski, Procedury kontroli przestrzegania praworządności i zasad demokracji przez Unię Europejska na przykładzie Węier i Polski, „Rocznik Integracji Europejskiej” 2016, nr 10, 229-241; Populist discourse in the Polish media, red. A. Stępińska, Poznań 2020.

10 R. Wike et al., Globally, Broad Support for Representative and Direct Democracy but many also endorse nondemocratic alternatives, https://www.pewresearch.org/global/2017/10/16/globallybroad-support-for-representative-and-direct-democracy/ (dostęp: 25.05.2021).

11 V-Dem, op. cit. 
jak Węgry, Polska, Turcja, Wielka Brytania, a do pewnego stopnia także Niemcy i Hiszpania, trudno nie odnieść wrażenia tożsamości strategii dyskursywnych czy też treści samych postulatów, związanych na przykład z częściowym demontażem instytucji konstytucyjnych ${ }^{12}$.

Do wzmożenia populistycznych, antydemokratycznych tendencji oraz do zaostrzenia sporu politycznego niewątpliwie przyczynił się także ogólnoświatowy kryzys ekonomiczny lat 2007-2009. O ile w mniejszym stopniu efekt ten może być obserwowalny w Polsce, o tyle w krajach Zachodu spowolnienie gospodarek, a w niektórych przypadkach recesja doprowadziły do poważnego nadszarpnięcia zaufania do elit intelektualnych. Zdaniem zwolenników narodowego populizmu internacjonalny kapitalistyczny wolny rynek, podlegający w wielu aspektach samoregulacjom, nie zareagował wystarczająco, by zapobiec kryzysowi oraz by przeciwdziałać jego skutkom, co odbiło się na obywatelach i krajowych gospodarkach. Mit eksperckich i nieomylnych elit runął już wtedy, a rozciągnięte w czasie negatywne efekty kryzysu dalej stopniowo rodziły niepokój i rosnącą frustrację wyborców, którzy czuli się oszukani ${ }^{13}$. Remedium na te emocje w swoich hojnych programach oferują politycy populistyczni, przedstawiający się jako jedyna ludowa alternatywa wobec elit. Tym samym wzmocniono i odświeżono (bo przecież nie jest to nic nowego) opozycję elity i ludu ${ }^{14}$, a jednocześnie przywołano wrażenie rozpoczęcia kolejnej wielkiej rewolucji.

W wypadku państw europejskich przyczyniły się do tego także kryzys uchodźczy związany z toczącą się od 2011 roku wojną w Syrii oraz migracje zarobkowe ze wschodniej Europy. W efekcie doszło do rozluźnienia więzi z tradycyjnymi partiami politycznymi, zakorzenionymi w państwowych strukturach od lat, co skutkowało niespotykanymi dotąd przepływami między elektoratami formacji politycznych. W USA te procesy były z kolei związane z gwałtownym wzrostem liczby mniejszości narodowych i etnicznych $\mathrm{w}$ ostatnich dekadach, a także z częstym podejmowaniem problemów tych grup przez Partię Demokratyczną, przez co pozostała część społeczeństwa zaczęła popierać polityków alternatywnych opcji (głównie Partii Republikańskiej, ale też ruchu Partii Herbacianej — TEA Party) ${ }^{15}$. Zgodnie z analizami prowadzonymi przez amerykańską socjolożkę Arlie Hochschild dotychczasowa większość uważa się za „obcych we własnym kraju”16.

12 Zob. S. Levitsky, D. Ziblatt, Tak umierają demokracje, przeł. O. Łabendowicz, Łódź 2018.

13 Zob. I. Krastew, S. Holmes, Explaining Eastern Europe: Imitation and its discontents, ,Journal of Democracy" 29, 2018, nr 3.

${ }^{14}$ Zob. R. Wodak, The "Establishment”, the "Élites", and the "People”: Who's who?, „Journal of Language and Politics" 16, 2017, nr 4, s. 551-565.

15 S. Levitsky, D. Ziblatt, op. cit., s. 199-203.

16 Zob. A.R. Hochschild, Strangers in Their Own Land: A Journey to the Heart of Our Political Divide, New York 2016 (A.R. Hochschild, Obcy we własnym kraju. Gniew i żal amerykańskiej prawicy, przeł. H. Pustuła, Warszawa 2017). 
Powyższe wydarzenia społeczne, ekonomiczne i polityczne mogą mieć wpływ na zmianę postaw obywateli przy wykorzystaniu mediów, wszak zgodnie z przyjętą konstruktywistyczną i systemową teorią komunikacji, całe poznanie świata bazuje na komunikacji, w tym komunikacji wspieranej i zapośredniczonej przez mass media ${ }^{17}$. W związku z tym należy przyjrzeć się bieżącym zjawiskom medialnym mającym wpływ na popularyzację tendencji antydemokratycznych, które bardzo często mają swoje podstawy w ruchach populistycznych.

\section{Populizm — operacjonalizacja pojęcia}

Jako że populizm jest zjawiskiem silnie związanym z wieloma ruchami antydemokratycznymi, należy w tym miejscu przyjrzeć się jego definicjom oraz stanowi dotychczasowych badań. Artur Lipiński, jeden z czołowych polskich badaczy tego tematu, w ramach prowadzonej metaanalizy podsumowuje, że wśród naukowców panuje pewien konsensus dotyczący głównej cechy dystynktywnej tego zjawiska, którą jest posługiwanie się antagonizmem lud-elity ${ }^{18}$. Stosowanie tej opozycji pozwala pozycjonować się aktorom sceny politycznej, odwołującym się do tych strategii, jako tym, którzy przeciwstawiają się zastanemu porządkowi społeczno-politycznemu. Posługiwanie się opozycją lud-elity ustawia ich też po stronie obywateli, a przeciwko, często określanemu jako skorumpowany albo skompromitowanemu, establishmentowi. Badania naukowe dotyczące tego obszaru opierają się na trzech kluczowych założeniach podstawowych. Pierwszym jest rozumienie populizmu w sferze idei — jako najważniejszej, ale też binarnej cechy ideologicznej poszczególnych polityków lub partii politycznych. Drugim — postrzeganie populizmu jako strategii, zbioru akcji i metod służących osiągnięciu danych celów. Wreszcie trzecim — traktowanie populizmu jako dyskursu, to znaczy jako właściwości prowadzonych komunikacji odznaczającej się charakterystycznymi zabiegami językowymi oraz pragmatyczno-językowymi ${ }^{19}$.

Każde z powyższych podejść nierozerwalnie wiąże się z architekturą i sposobami konsumpcji współczesnych mediów, w tym (szczególnie, ale nie jedynie) social mediów. W dalszej części artykułu omówione zostaną te cechy, które mogą mieć bezpośredni wpływ na popularyzację tez populistycznych.

\section{Strategie medialne a walka polityczna}

Początkowo ekstatyczne opisy możliwości zyskujących na popularności nowych mediów, mediów sieciowych, czyli mediów opierających się na narzędziach Web 2.0, w miarę postępu swoistej immersyjności doczekały się gorzkich wery-

17 N. Luhmann, Realność mediów masowych, przeł. J. Barbacka, Wrocław 2009, s. 7.

18 A. Lipiński, W poszukiwaniu ontologii populizmu — dylematy definicyjne, ,Przegląd Polityczny" 2020, nr 1, s. 144-145.

19 Ibidem, s. 132-137. 
fikacji. Technologia, mająca rozwiązać wiele problemów komunikacyjnych, lokacyjnych, społecznych czy potencjalnie służąca rozwojowi demokratyzacji, nie pozostała bez często negatywnego wpływu na każdy z wymienionych obszarów. W początkowej fazie wraz z rozwojem technologicznym postulowano utworzenie się tak zwanej technokultury, co miało się wiązać między innymi z nasileniem procesów globalizacyjnych czy zastąpieniem epoki przemysłowej wiekiem prymatu informacji oraz zwiększeniem wpływu mediów na sytuację geopolityczną 20 . Wśród licznych i niewątpliwych zalet samego internetu wymieniano otwartość, globalność, interaktywność i elastyczność ${ }^{21}$, a także powstanie cyberdemokacji i rozwój demokratyzacji, co uzasadniane jest przez popularyzację demokracji bezpośredniej, zwrócenie uwagi na istotę partycypacji społecznej czy możliwość sprawiania, by rosła zauważalność poglądów dotychczas marginalizowanych ${ }^{22}$. Nie brakowało opinii, że nowe media dzięki swojej interaktywności i aktualności są powrotem do źródeł demokracji, a tym samym internet postrzegany być może jako odpowiednik ówczesnej agory ${ }^{23}$.

Jednak postępująca dezintermediacja skonwergowanych mediów niesie z sobą także wiele negatywnych zjawisk, w tym między innymi łatwe rozprzestrzenianie się fake newsów, szerzenie dezinformacji oraz potocyzacja języka polityki. Rozpowszechnienie mediów sieciowych i narzędzi z nim związanych niesie ze sobą zarówno szanse, jak i zagrożenia. Do pierwszych zalicza się często wzmocnienie jednostek, rozwój, możliwość integracji społeczności, natomiast wśród negatywnych skutków wymienia się zaburzenie relacji interpersonalnych oraz wzmocnienie podziałów i nierówności ${ }^{24}$. Zapewne znaczącą rolę w tym procesie odgrywają właśnie social media ${ }^{25}$, które ze względu na swoją architekturę wytworzyły u odbiorców specyficzny sposób konsumowania treści — znany dotychczas z mediów tradycyjnych model jeden-do-wielu ustąpił miejsca modelowi

20 M. Lister et. al., Nowe media. Wprowadzenie, przeł. M. Lorek, A. Sadza, K. Sawicka, Kraków 2007, s. 10-13.

21 T. Flew, Media globalne, przeł. M. Lorek, Kraków 2007, s. 27.

22 M. Musiał-Karg, Wplyw ICT na życie polityczne, [w:] Nowe media we współczesnym świecie, red. M. Jeziński, A. Seklecka, Ł. Wojtkowski, Toruń 2011, s. 278-280.

${ }^{23}$ L. Porębski, Elektroniczne oblicze polityki. Demokracja, państwo, instytucje polityczne w okresie rewolucji informatycznej, Kraków 2001, s. 73.

${ }^{24}$ K. Schwab, Dokąd zaprowadzi nas czwarta rewolucja przemystowa, https://wszystkoconajwazniejsze.pl/klaus-schwab-dokad-zaprowadzi-nas-czwarta-rewolucja-przemyslowa/ (dostęp: 10.06.2021).

25 Celowym zabiegiem jest użycie w artykule anglojęzycznego wyrażenia „social media” w miejscu polskiego, dość powszechnego, acz niefortunnego odpowiednika „media społecznościowe", co wynika z toczącej się debaty dotyczącej i reprezentowanego przez autora stanowiska na ten temat: nikłego ich odniesienia do wytwarzania i stabilizowania społeczności (zob. na przykład M. Fleischer, Konstrukcja rzeczywistości 3, Kraków 2017; H. Welzer, Die smarte Diktatur. Der Angriff auf unsere Freiheit, Frankfurt am Main 2016). 
wielu-do-wielu ${ }^{26}$. Tym samym rola strażników (ang. gatekeepers), czyli mechanizmów i osób selekcjonujących treści przed ich udostępnieniem, znacząco osłabła, co wzmocniło pozycję social mediów jako autentycznych i niefiltrowanych źródeł informacji. Wspomniana autentyczność jest właśnie jedną z najbardziej pożądanych cech przez populistycznych aktorów sceny politycznej, dlatego serwisy te wydają się ich pierwszym wyborem do prezentowania swoich tez. Oczywiście wspomniane pierwszeństwo wynika także z utrudnionego dostępu do mediów tradycyjnych, które w procesie filtrowania treści często rezygnują z publikowania niezweryfikowanych informacji.

Dzięki znikomej liczbie mechanizmów selekcyjnych social media pozwalają na publikowanie wpisów bez konieczności przechodzenia redakcji i korekty, do czego przyzwyczaili się użytkownicy internetu już od jego wczesnych lat, a więc treści elektroniczne nierzadko zawierają błędy językowe, a także cechują się wysokim poziomem emocjonalizacji wypowiedzi. Obie te cechy stanowią jedne z elementów dystynktywnych stylu populistycznego, wywierających potencjalnie poczucie autentyczności ${ }^{27}$. Analizy prowadzone wśród włoskich polityków pozwoliły wyodrębnić cztery główne typy stylu populistycznego:

- obrońca ludu: odznaczający się antyelityzmem oraz nieskomplikowanym i nieformalnym językiem,

— człowiek z ulicy: cechujący się użyciem wulgarnego i nieobywatelskiego języka oraz odniesień do strachu,

— styl intymny: charakteryzujący się spersonalizowanym komunikatem, niestroniącym od emocji, bazującym na eksponowaniu prywatności,

— styl angażujący: wykorzystywany w celach autopromocyjnych w kontekście mobilizującym elektorat ${ }^{28}$.

Wzajemne oddziaływanie i relacje pomiędzy populistami a sposobami działania social mediów, bazującymi na algorytmach doboru treści, odnotowują liczni badacze $^{29}$. Dodatkowo wytworzone przez media sieciowe mechanizmy konsumpcji informacji doprowadziły do powstania komór pogłosowych ${ }^{30} \mathrm{i}$ baniek filtrują-

26 A. Lipiński, Populizm a medialne struktury możliwości. Przypadek nowych mediów, „Władza Sądzenia (Power of Judgement)" 2020, nr 19, s. 80.

27 Ibidem, s. 87.

28 R. Bracciale, A. Martella, Define the populist political communication style: The case of Italian political leaders on Twitter, „Information, Communication \& Society” 20, 2017, nr 9, s. 13101329, przyp. za: A. Lipiński, Populizm..., s. 87.

29 Zob. S. Bennett et al., Populist Communication on Social Media, Centre for Social Sciences, Centre of Excellence of the Hungarian Academy of Sciences 2020; S. Blassnig et al., Populism and Social Media Popularity. How populist communication benefits political leaders on Facebook and Twitter, [w:] Power Shift? Political Leadership and Social Media, New York 2019; J. Jakubowski, Populizm i social media — matżeństwo z rozsadku?, ,e-Politikon” 2017, nr 24, s. 30-86.

30 Zob. C.R. Sunstein, \#Republic: Divided Democracy in the Age of Social Media, Princeton 2017. 
cych $^{31}$, czyli sytuacji, w których użytkownicy nie mogą w łatwy sposób poznać opinii spoza ich obrazu świata poprzez ograniczenie ich widoczności w poszczególnych serwisach (ale także wyszukiwarkach, portalach informacyjnych itp.). Ciekawe rozróżnienie obu tych pojęć proponuje Paweł Matuszewski:

Przez bańkę filtrującą rozumiem następującą sytuację: treści są dostarczane użytkownikowi przez algorytmy, które je wybierają na podstawie jego wcześniejszych zachowań. Innymi słowy, komory pogłosowe są efektem dyskusji jednostek o podobnych poglądach, a bańki filtrujące to efekt funkcjonowania algorytmów selekcjonujących treści ${ }^{32}$.

Oba zjawiska doczekały się relatywnie licznych opracowań ${ }^{33}$, również oba łączy specyficzny efekt, którym jest pogłębienie polaryzacji społeczeństwa. Wspomniane algorytmy dostosowują treści wyświetlane użytkownikom na podstawie trendów oraz ich wcześniejszych aktywności. W efekcie zadowolony odbiorca (wszak bez zbędnego trwonienia czasu może dotrzeć do interesujących go materiałów) obdarza zaufaniem dany serwis i tym samym zamyka się w czterech ścianach swoich własnych przekonań ${ }^{34}$, a z perspektywy koncernów medialnych staje się zaszufladkowanym użytkownikiem, jednym z wyników podlegających analizom z zakresu big data.

Następnie tacy pojedynczy, stypizowani konsumenci (zgodnie z przyjętym konsumpcyjnym modelem funkcjonowania mediów) stają się odbiorcami odpowiednio sprofilowanej reklamy ${ }^{35}$, także reklamy politycznej, która w obecnych czasach przyjmuje różne formy. Dzięki stosunkowo łatwo dostępnym danym (co pokazał przykład Cambrigde Analytica ${ }^{36}$ ) politycy mogą w pierwszej kolejności odpowiednio skonstruować swój program wyborczy w kontekście preferencji dużych grup elektoratu, a następnie utrwalać swój przekaz w serwisach, dostosowując się do bieżących i dominujących stylów i sposobów komunikacji odbiorców. Zachowania takie sprzyjają także promowaniu komunikacji polaryzujących, budowaniu samopotwierdzających się schematów myślowych oraz utrwalaniu stereotypów ${ }^{37}$.

Architektura globalnych social mediów narzuca konkretne przyzwyczajenia oraz jednolity sposób konsumowania treści. Natłok informacyjny oraz zjawisko określane jako FOMO (ang. fear of missing out) powodują, że użytkownicy, uza-

31 Zob. E. Pariser, The Filter Bubble: What the Internet is hiding from you, London 2011.

32 P. Matuszewski, Cyberplemiona. Analiza zachowań użytkowników Facebooka $w$ trakcie kampanii parlamentarnej, Warszawa 2018, s. 103.

33 Zob. M. Schaub, D. Morisi, Voter mobilization in the echo chamber: Broadband internet and the rise of populism in Europe, „European Journal of Political Research” 59, 2019, nr 4; H. Welzer, Samodzielne myślenie, przeł. V. Grotowicz, Słupsk 2016.

${ }^{34}$ C.R. Sunstein, op. cit., s. 5.

35 M. Fleischer, op. cit., s. 152-161.

36 Zob. Ch. Wylie, Mindf*ck. Cambridge Analytica, czyli jak popsuć demokracje, przeł. M. Strąkow, Kraków 2020.

37 R.K. Merton, Teoria socjologiczna i struktura społeczna, przeł. E. Morawska, J. Wertenstein-Żuławski, Warszawa 2002, s. 74-77. 
leżnieni od poznawania nowych wiadomości, nie są w stanie przyswoić napływających newsów, co prowadzi do stopniowego odejścia od wnikliwego albo nawet połowicznie uważnego czytania treści na rzecz ich skanowania (często samych nagłówków). Funkcjonowanie w komorach pogłosowych sprawia, że potencjalny odbiorca nie kwestionuje przeczytanej informacji, przyjmuje ją niemal bezkrytycznie, o ile jest spójna z jego obrazem świata, przy czym wiadomości sprzeczne z tymże zostaną najpewniej odrzucone przy okazji działania algorytmów filtrujących.

Wiele badań dotyczących styku mediów i polityki w ostatnich latach podejmowało temat zjawiska dezinformacji ${ }^{38}$. Należy zwrócić uwagę, że pojęcie to nie jest tożsame z kłamstwem. Tomasz Aleksandrowicz definiuje je jako

taki sposób przekazania informacji — prawdziwej lub fałszywej — aby wprowadzić w błąd przeciwnika/konkurenta i skłonić go do zachowania zgodnego z naszymi oczekiwaniami i korzystnego dla nas. Dezinformacja nie jest prostym kłamstwem, czyli przekazaniem fałszywej informacji; jest podstępem. $Z$ reguły akcja dezinformacji polega na przekazywaniu całego konglomeratu, z których większość jest prawdziwa, a tylko jedna — kluczowa dla wywołania zakładanego efektu jest informacją fałszywą. Zdarza się też, że akcja dezinformacyjna przeprowadzana jest w oparciu o informacje prawdziwe, lecz podane w taki sposób, iż konkurent uznaje je za fałszywe. Dla zwiększenia skuteczności, przy stosowaniu dezinformacji wykorzystuje się kilka niezależnych od siebie źródeł i kanałów informacyjnych ${ }^{39}$.

Bezpośrednio ze zjawiskiem dezinformacji związane są pojęcia fake news i wojna informacyjna. Fake news bywa określany jako wiadomość nieodpowiadająca faktom, która jest zmanipulowana lub niedokładna ${ }^{40}$ i która może być (ale nie musi) elementem dezinformacji. Kolejne analizy pokazują spadające zaufanie do mediów tradycyjnych ${ }^{41}$, co wpływa na znaczący wzrost popularności nieprawdziwych informacji, których głównym rezerwuarem jest internet (a szczególnie social media). W zmediatyzowanym świecie jedną z priorytetowych cech wiadomości jest szybkość ich publikacji. Do rozprzestrzeniania się nieprawdziwych treści bardzo często wykorzystywane są kolejne nowoczesne technologie, na przykład boty, które w sposób zautomatyzowany produkują treści, będące nierzadko dezinformacją albo wsparciem dla wybranych kandydatów ${ }^{42}$. Następnym zjawiskiem, które warunkuje poczucie autentyczności i błyskawiczne tworzenie się fake newsów,

38 Zob. na przykład Postprawda. Spojrzenie krytyczne, red. T. Grabowski et al., Kraków 2018; M. d'Ancona, Postprawda, przeł. M. Sutowski Warszawa 2018; D.A. Barclay, Fake News, Propaganda, and Plain Old Lies. How to Find Trustworthy, London 2018.

39 T.R. Aleksandrowicz, Podstawy walki informacyjnej, Warszawa 2016, s. 83.

40 M. Chyliński, Fatszywe wiadomości - antydobra w ekosystemie informacji, „Com.press” 4, 2018, nr 1, s. 9.

41 P. Bedard, Fishwrap: Just 2\% of younger Americans trust media to 'do the right thing', http:// www.washingtonexaminer.com/harvard-media-dead-last-on-trust-list-behindu.n.-congress-obama/ article/2563763 (dostęp: 30.05.2021).

42 B. Łódzki, Fake news - dezinformacja w mediach internetowych i formy jej zwalczania w przestrzeni międzynarodowej, „Polityka i Społeczeństwo” 16, 2017, nr 4, s. 21-22. 
jest trolling, czyli wykorzystywanie fałszywych profili do wspierania i multiplikowania konkretnych narracji i przekazów. Zakładane w tym celu tak zwane farmy trolli mają za zadanie publikować w social mediach liczne komentarze służące propagowaniu wybranych tez przy wykorzystaniu wielu fikcyjnych tożsamości. Najszerzej odnotowana w literaturze jest działalność rosyjskich farm trolli, która skupia się na wykorzystaniu dezinformacji do zaburzenia debaty publicznej, zwiększenia polaryzacji i antagonizmów w społeczeństwie oraz nadszarpnięcia zaufania do instytucji, a także międzynarodowych sojuszy ${ }^{43}$. Edward Lucas i Peter Pomeranzev, brytyjscy publicyści i dziennikarze śledczy, wskazują, że polityka Rosji odpowiada między innymi za wywołanie powstania antyrządowego we wschodniej Ukrainie, osłabienie pozycji Łotwy czy wsparcie ruchów opozycyjnych w Polsce w ciągu lat bezpośrednio poprzedzających badanie ${ }^{44}$.

Tego typu zabiegi mogą być ogromnym zagrożeniem dla demokracji. Analizy dotyczące nadużyć w czasie wyborów prezydenckich w Stanach Zjednoczonych w latach 2010, 2016 i 2020 wskazują na ich istotny wpływ na wynik wyborczy ${ }^{45}$. Choć przytoczone tu przykłady wykorzystania informacji $\mathrm{w}$ łagodnym ujęciu mogą mieć znamiona działań przestępczych, mechanika działania dezinformacji w przypadku poszczególnych państw czy pojedynczych polityków pozostaje taka sama, a jej celem jest podważenie zastanego porządku społeczno-politycznego przez zachwianie wiary w prawdziwość publikowanych informacji, a tym samym spadek zaufania społecznego.

\section{Podsumowanie}

Jak wykazała przeprowadzona analiza, architektura i mechanika działania współczesnych mediów umożliwiają w znacznym stopniu personalizację i dostosowanie przekazu do odbiorcy, ograniczają mechanizmy filtrujące, a także pozwalają na upowszechnienie nieformalnej komunikacji także w sytuacjach oficjalnych. Elementy te dopuszczają i promują tym samym nowych oraz nierzadko odznaczających się kontrowersyjnymi poglądami aktorów politycznych, dając im możliwość dotarcia do szerokiego elektoratu z pominięciem mediów tradycyjnych. Niewątpliwie z jednej strony sytuacja ta służy demokratyzacji, jednak umiejętnie jest też wykorzystywana przez ruchy populistyczne, a nawet przez poszczególne

43 Zob. O. Wasiuta, S. Wasiuta, Kremlowska dezinformacja w Internecie i reakcja społeczeństw zachodnich, „Przegląd Geopolityczny” 2020, nr 34, s. 136-147.

${ }^{4}$ Zob. E. Lucas, P. Pomeranzev, Winning the Information War Techniques and Counter-strategies to Russian Propaganda in Central and Eastern Europe. A Report by CEPA's Information Warfare Project in Partnership with the Legatum Institute, Washington 2016.

45 Zob. J. Misiuna, Dezinformacja a proces wyborczy: studium przypadku wyborów prezydenckich w Stanach Zjednoczonych, [w:] Przeciwdziałania dezinformacji - budowanie odporności spotecznej badania i edukacja, red. R. Kupiecki et al., Warszawa 2021. 
państwa w celu wzmocnienia wybranej strategii komunikacyjnej. Wszak swoisty sojusz między populistami a mediami sieciowymi wynika ze wspólnych podstaw istnienia: social media, tak jak i formacje populistyczne, utworzone zostały niejako w opozycji do bieżącej sytuacji zastanej, ugruntowanej pozycji tradycyjnych partii i mediów, umożliwiającej im decydowanie o tym, kto do danego dyskursu zostanie dopuszczony, a kto nie.

Mechanizmy dezinformacyjne, stosowane algorytmy filtrowania treści, komory pogłosowe wzmacniają podziały społeczne oraz przyczyniają się do spadku zaufania społecznego, będącego podstawą funkcjonowania społeczeństwa. Bez wątpienia ten ciąg przyczynowo-skutkowy wpływa docelowo na zmniejszenie się poziomu demokratyzacji na świecie w ciągu ostatnich 30 lat. Proces ten może się pogłębiać, dlatego bardzo istotne jest wytworzenie wewnętrznych mechanizmów obronnych przez państwa i aktorów demokratycznych, szczególnie w zakresie edukacji społeczeństwa i pogłębiania idei społeczeństwa obywatelskiego. Należy jednak podkreślić, że stosunkowo wysokie poparcie dla populistycznych aktorów sceny politycznej nie jest zasługą jedynie mechanizmów medialnych, które nie promują żadnego konkretnego podejścia czy ideologii, a jedynie są stymulowane przez reprezentujących je polityków. Dodatkowy, niewątpliwie istotny wpływ na popularność populistycznych tez i ich głosicieli mają także pozostałe czynniki społeczne, polityczne, ekonomiczne, wynikające z bieżącej sytuacji na świecie. Być może więc w myśl kapitalistycznej zasady konkurencyjności ci aktanci po prostu przystosowali swoje komunikacje pod względem zarówno treści, jak i strategii do znalezionej niszy, w której wydają się czuć komfortowo. Niemniej panująca w sieci kakofonia poszczególnych idei i poglądów, a także opisane w artykule mechanizmy konsumpcji treści nie wpływają na zwiększenie refleksji wśród potencjalnych odbiorców tych komunikatów, co może być i jest wykorzystywane do celów większych strategii dezinformacyjnych.

\section{Bibliografia}

Aleksandrowicz T.R., Podstawy walki informacyjnej, Warszawa 2016.

Ancona M. d', Postprawda, przeł. M. Sutowski, Warszawa 2018.

Barclay D.A., Fake News, Propaganda, and Plain Old Lies: How to Find Trustworthy, London 2018. Bedard P., Fishwrap: Just 2\% of younger Americans trust media to 'do the right thing', http://www. washingtonexaminer.com/harvard-media-dead-last-on-trust-list-behindu.n.-congress-obama/article/2563763.

Bell D., The End of Ideology? On the Exhaustion of Political Ideas in the 1950s, New York 1960.

Bennett S., Lipiński A., Stępińska A., Abadi D., Gammeltoft-Hansen T., Hubé N., Baloge M., Bobba G., Butkeviciene E., Brands C., Kocián J., Populist Communication on Social Media, Budapest 2020.

Blassnig S., Ernst N., Engesser S., Esser F., Populism and Social Media Popularity. How populist communication benefits political leaders on Facebook and Twitter, [w:] Power Shift? Political Leadership and Social Media, New York 2019. 
Blombäck S., Populism as a challenge to liberal democracy in Europe, [w:] The European Union in a Changing World Order, red. A. Bakardjieva Engelbrekt, N. Bremberg, A. Michalski, L. Oxelheim, Cham 2020.

Bracciale R., Martella A., Define the populist political communication style: The case of Italian political leaders on Twitter, „Information, Communication \& Society” 20, 2017, nr 9.

Chyliński M., Fatszywe wiadomości - antydobra w ekosystemie informacji, „Com.press” 4, 2018, nr 1.

Crick B., W obronie polityki, przeł. A. Waśkiewicz, Warszawa 2004.

Diamond L., Democracy Demotion: How the Freedom Agenda Fell Apart, „Foreign Affairs” 98, 2019, nr 2.

Drinóczi T., Bień-Kacała A., Illiberal Constitutionalism: The case of Hungary and Poland, „German Law Journal” 20, 2019, nr 8, s. 1140-1166.

Eatwell R., Goodwin M., Narodowy populizm. Zamach na liberalna gospodarke, przeł. W. Kurylak, Katowice 2020.

The Economist Intelligence Unit, Democracy Index 2020: In sickness and in health? www.eiu.com/ topic/democracy-index.

Fleischer M., Konstrukcja rzeczywistości 3, Kraków 2017.

Flew T., Media globalne, przeł. M. Lorek, Kraków 2007.

Fukuyama F., Koniec historii, przeł. T. Bieroń, M. Wichrowski, Poznań 1997.

Heywood A., Politologia, przeł. B. Maliszewska et al., Warszawa 2006.

Hochschild A.R., Obcy we własnym kraju. Gniew i żal amerykańskiej prawicy, przeł. H. Pustuła, Warszawa 2017.

Hochschild A.R., Strangers in Their Own Land: A Journey to the heart of our political divide, New York 2016.

Jakubowski J., Populizm i social media - matzeństwo z rozsadku?, „e-Politikon” 2017, nr 24, s. $30-86$.

Jaskulski A., Procedury kontroli przestrzegania praworzadności i zasad demokracji przez Unię Europejska na przykładzie Węgier i Polski, „Rocznik Integracji Europejskiej” 2016, nr 10.

Krastew I., Holmes S., Explaining Eastern Europe: Imitation and its discontents, „Journal of Democracy" 29, 2018, nr 3.

Levitsky S., Ziblatt D., Tak umierają demokracje, przeł. O. Łabendowicz, Łódź 2018.

Lipiński A., Populizm a medialne struktury możliwości. Przypadek nowych mediów, „Władza Sądzenia (Power of judgement)" 2020, nr 19.

Lipiński A., W poszukiwaniu ontologii populizmu — dylematy definicyjne, „Przegląd Polityczny” 2020, $\mathrm{nr} 1$.

Lister M., Dovey J., Giddings S., Grant I., Kelly K., Nowe media. Wprowadzenie, przeł. M. Lorek, A. Sadza, A. Sawicka, Kraków 2007.

Lucas E., Pomeranzev P., Winning the Information War Techniques and Counter-strategies to Russian Propaganda in Central and Eastern Europe. A Report by CEPA's Information Warfare Project in Partnership with the Legatum Institute, Washington 2016.

Luhmann N., Realność mediów masowych, przeł. J. Barbacka, Wrocław 2009.

Łódzki B., Fake news - dezinformacja w mediach internetowych i formy jej zwalczania w przestrzeni międzynarodowej, „Polityka i Społeczeństwo” 16, 2017, nr 4.

Matuszewski P., Cyberplemiona. Analiza zachowań użytkowników Facebooka w trakcie kampanii parlamentarnej, Warszawa 2018.

Merton R.K., Teoria socjologiczna i struktura społeczna, przeł. E. Morawska, J. Wertenstein-Żuławski, Warszawa 2002. 
Misiuna J., Dezinformacja a proces wyborczy: studium przypadku wyborów prezydenckich $w$ Stanach Zjednoczonych, [w:] Przeciwdziatania dezinformacji — budowanie odporności społecznej badania i edukacja, red. R. Kupiecki et al., Warszawa 2021.

Müller J.-W., Co to jest populizm?, przeł. M. Sutowski, Warszawa 2017.

Musiał-Karg M., Wpływ ICT na życie polityczne, [w:] Nowe media we wspótczesnym świecie, red. M. Jeziński, A. Seklecka, Ł. Wojtkowski, Toruń 2011.

Pariser E., The Filter Bubble: What the Internet is hiding from you, London 2011.

Populist discourse in the Polish media, red. A. Stępińska, Poznań 2020.

Porębski L., Elektroniczne oblicze polityki. Demokracja, państwo, instytucje polityczne w okresie rewolucji informatycznej, Kraków 2001.

Postprawda. Spojrzenie krytyczne, red. T. Grabowski, M. Lakomy, K. Oświecimski, A. Pohl, Kraków 2018.

Ross E.W., The problem of democracy in the time of Trump, „Educazione Aperta” 2020, nr 6.

Schaub M., Morisi D., Voter mobilization in the echo chamber: Broadband internet and the rise of populism in Europe, „European Journal of Political Research” 59, 2019, nr 4.

Schwab K., Dokad zaprowadzi nas czwarta rewolucja przemystowa, https://wszystkoconajwazniejsze.pl/klaus-schwab-dokad-zaprowadzi-nas-czwarta-rewolucja-przemyslowa/.

Sunstein C.R., \#Republic: Divided Democracy in the Age of Social Media, Princeton 2017.

V-Dem, Autocratization Turns Viral. Democracy Report 2021, https://www.v-dem.net/media/filer_ public/74/8c/748c68ad-f224-4cd7-87f9-8794add5c60f/dr_2021_updated.pdf.

Wasiuta O., Wasiuta S., Kremlowska dezinformacja w Internecie i reakcja społeczeństw zachodnich, „Przegląd Geopolityczny” 2020, nr 34.

Welzer H., Samodzielne myślenie, przeł. V. Grotowicz, Słupsk 2016.

Welzer H., Die smarte Diktatur. Der Angriff auf unsere Freiheit, Frankfurt am Main 2016.

Wike R., Simmons K., Stokes B., Fetterolf J., Globally, Broad Support for Representative and Direct Democracy but many also endorse nondemocratic alternatives, https://www.pewresearch.org/ global/2017/10/16/globally-broad-support-for-representative-and-direct-democracy/.

Wodak R., The "Establishment", the "Élites”, and the "People”: Who's who?, „Journal of Language and Politics" 16, 2017, nr 4, s. 551-565.

Wylie Ch., Mindf*ck. Cambridge Analytica, czyli jak popsuć demokrację, przeł. M. Strąkow, Kraków 2020. 